Int. J. Dev. Biol. 51: 339-343 (2007)

doi: $10.1387 / \mathrm{ijdb} .062235 \mathrm{js}$

Developmental Expression Pattern

\title{
Expression and regulation of Xenopus CRMP-4 in the developing nervous system
}

\author{
JACOB SOUOPGUI ${ }^{1}$, TIEMO J. KLISCH, TOMAS PIELER and KRISTINE A. HENNINGFELD* \\ DFG-Center of Molecular Physiology of the Brain, Department of Developmental Biochemistry, University of Goettingen, \\ Goettingen, Germany
}

\begin{abstract}
The collaspin response mediator proteins (CRMPs) are a family of cytosolic phosphoproteins which play a critical role in the establishment of neuronal polarity and growth cone guidance. Here, we describe the temporal and spatial expression of CRMP-4 during early Xenopus embryogenesis. CRMP-4 transcripts were first detected by whole mount in situ hybridization at the end of gastrulation in the prospective neuroectoderm. During open neural plate stages, CRMP. 4 was expressed broadly throughout the anterior neural plate and in the three bilateral stripes of the posterior neural plate where primary neurons arise. The expression in the territories of primary neurogenesis prefigures that of the post-mitotic neuronal marker $\boldsymbol{N}$-tubulin. At tadpole stages, expression was maintained throughout the central nervous system and in the retina of the eye. Consistent with the observed expression, CRMP-4 transcripts are positively regulated by X-ngnr1 and negatively by Notch signaling. The observed expression and regulation of CRMP-4 differ from that of the CRMP-2, which is induced by the events of neural induction.
\end{abstract}

KEY WORDS: Xenopus, primary neurogenesis, neurogenin, CRMP, Notch

The collapsin response mediator proteins (CRMPs) (also known as TOAD (turned on after division), Ulip (unc-33 like protein) and DRP (dihydropyrimidinase family) are a conserved family of cytosolic phosphoproteins highly expressed in the nervous system (Wang and Strittmatter, 1996). Even though the CRMPs exhibit more than $60 \%$ amino acid identity to the amidohydrolase family, they do not possess enzymatic activity (Wang and Strittmatter, 1997).

The first CRMP was identified as an intracellular mediator of semaphorin/collapsin growth cone collapse (Goshima et al., 1995). However, numerous studies have demonstrated that the activities of CRMPs are not restricted to this repulsive guidance cue and participate in a broad spectrum of additional activities, with function being dependant on the specific interaction with various protein partners (Arimura et al., 2004). CRMP-2 participates in LPA-induced growth cone collapse and regulates axonogenesis through the binding of tubulin heterodimers (Inagaki et al., 2001; Fukata et al., 2002). CRMP-2 also contributes to the establishment of neuronal polarity through the association with Numb and promoting Numb-mediated endocytosis of the neuronal cell adhesion molecule L1 (Nishimura et al., 2003).
CRMP proteins are also targets of a variety of protein kinases. CRMP-2 and CRMP-4 were identified as brain-specific substrates for glycogen synthase kinase 3 (GSK3) and during growth cone collapse, phosphorylation by Rho-associated kinase inhibits microtubule assembly and Numb-mediated endoyctosis (Arimura et al., 2005; Yoshimura et al., 2005; Cole et al., 2006). Recently, CRMP-2 was identified as a negative regulator of p53 and it has been suggested to play a role in the regulation of proliferation (Llanos et al., 2006; Tahimic et al., 2006). Moreover, the CRMPs may contribute to the pathogenesis of specific neurodegenerative disorders (Charrier et al., 2003).

Presently, we describe the expression analysis of CRMP-4, during early Xenopus embryogenesis. CRMP-4 is expressed in the differentiating primary neurons and later expression is maintained throughout the central nervous system and in the eye. Correspondingly, CRMP-4is positively regulated by X-ngnr-1 and negatively regulated by the Notch pathway.

Abbreviations used in this paper: CRMP, collapsin response mediator protein; DRP, dihydropyrimidinase; GSK3, glykogen synthase kinase 3; TOAD, turned on after division; Ulip, unc-33 like protein.

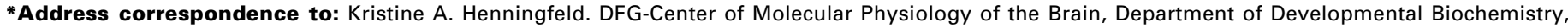
University of Goettingen, Justus-von-Liebig Weg 11, 37077 Goettingen, Germany. Fax: +49-551-391-4614. e-mail: khennin1@gwdg.de
}

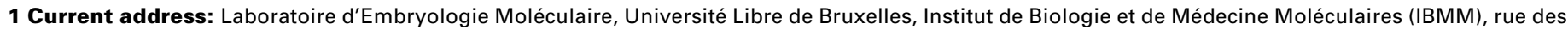
Profs. Jeener et Brachet 12, 6041 Gosselies, Belgium 


\section{Results and Discussion}

Xenopus CRMP-4 was identified in a microarray screen aimed at identifying genes induced in dissociated ectodermal explants by the neuronal determination transcription factor, X-ngnr-1. Comparison of the predicted amino acid sequence revealed Xenopus CRMP-4 is $90 \%$ identical to the corresponding human and mouse sequences. Lower identity was observed between Xenopus CRMP-2 (75\%) and other mammalian CRMP members (71-74\%) (Fig. 1). The Cdk5 priming and GSK3 phosphorylation sites identified in the mammalian CRMP-2 are conserved (Uchida et al., 2005; Yoshimura et al., 2005).

The expression of CRMP-4during early Xenopusembryogenesis was investigated by RT-PCR analysis with RNA isolated from various stages of development (Fig. 2A). Zygotic transcripts of
CRMP-4 were detected at low levels by the end of gastrulation, increased during neurula stages and were maintained at constant levels throughout tailbud stages and later development.

As shown in Figure $2 \mathrm{~B}$ and $2 \mathrm{C}$, transcripts are first detected at stage 11.5 by whole mount in situhybridization, broadly throughout the prospective neural ectoderm. At stage $12.5, C R M P-4$ is enriched in the anterior neural plate and two longitudinal stripes flanking the midline (Fig. 2D). As development proceeds, the posterior expression becomes more prominent and CRMP-4 is strongly detected throughout the territories of primary neurogenesis including the medial, intermediate and lateral stripes, where motor-, inter- and sensory neurons will later differentiate, respectively (Fig. 2E-G) (Chitnis et al., 1995). This pattern of expression is similar to that of proneural transcription factors and prefigures that of the neural specific $\beta$-tubulin ( $\mathrm{N}$-tubulin), which marks terminally differentiated neurons (Oschwald et al., 1991). Transcripts are still detected broadly throughout the anterior neural plate and in a lateral group of cells associated with the trigeminal ganglia. Neuronal differentiation in the anterior neural plate is delayed until tadpole stages, thus in contrast to CRMP-4, known proneural genes are absent from this territory (Papalopulu and Kintner, 1996). This restricted expression in the posterior neural plate contrasts the panneural expression of Xenopus CRMP-2 (Kamata et al., 1998).

During neurula and early tailbud stages, CRMP4 transcripts are found throughout the central nervous system including the developing brain and neural tube, as well as the eye (Fig 2I-K). As shown by the transversal section, transcripts of CRMP-4are present primarily in the subventricular and outer marginal layers of the neural tube (Fig $2 \mathrm{~L}$ ), where cells that initiate differentiation and post-mitotic cells are localized, respectively. Additionally, in the anterior ventrolateral region of the embryo, a scattered ring of cells expresses $C M P R$ 4. A transversal section demonstrates that these are isolated cells lying immediately below the ectoderm (Fig. 2M). These CRMP-4 expressing cells are maintained through tailbud stages but disappear at tadpole stages (compare Fig. $2 \mathrm{~K}$ and $\mathrm{N})$. This punctuate pattern is similar to that of Xphox2Aand XHand2and has been suggested to be progenitors of smooth muscle cells or pericytes of the forming vasculature (Smith et al., 2000; Talikka et al., 2004). Interestingly, we have also observed a similar punctuate expression by other proneural genes such as $X-M y T 1$ (data not shown) and $N$-tubulin (Fig 2P) suggesting they are neuronal cells. At tadpole stages (Fig. 2N), CRMP-4 expression is maintained in the CNS, the eye, as

XCRMP 4 420VSAKSHHSAAEYNIFEGMELRGAPLVVICQGKIMMEDGTLHATQGTGRFIPCSPEPDYVY

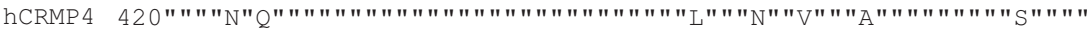
hCRMP2 420I"" T"N"SL" " " " " " "C" "S" " " "S" " "VL" " " " "V"E"S" "Y" "RK" " "F" " XCRMP2 421 I" " T"N"NV" " " " " " "C" "S" " " "S" " "VL"E" " " " "E"S" "Y" "RK" " " " " "

XCRMP 4 480KRIKARTKMAELHAVPRGMYDGPVHDLASTPKAGTPAGSTKGSPTKQ TA PVRNLHHSG hCRMP4 480" " " " "R" " "D" " " " " " " " " " "F" "TT" " "G" " " " "AR" " "RP_NP_" " " " "Q" "

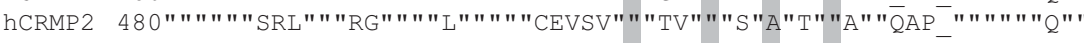
XCRMP2 481" " " " "SRL" "RG" " "L" " " "CEVSV"" "V" " "S"A"T" "A" " P"С" I" " "Q"

XCRMP 4 538FSLIGNQADESGVRSASRRIVAPPGGRSNITSLS hCRMP4 538 "" "S"T"V" " " " " "K" " " " " " " " " " " " " hCRMP2 539"""S"A"I"DÑIP"RTTQ" " " " " ""A" "" "G XCRMP2 540 ""S"A"V"DNIP"RTTQ"""" """""A"""""G

Fig. 1. Amino acid alignment of the predicted open reading frame (ORF) of Xenopus CRMP-4 and CRMP-2, with the corresponding human sequences. Identical amino acids are indicated by ditto (") marks. Phosphorylation sites known for the mammalian CRMP-2 are shaded in gray and include the Cdk5 priming site (S522) for GSK3b phosphorylation (T509, T514 and S518), as well as the CRMP-2 Rhoassociated kinase target site (S555) (Arimura et al., 2000, Uchida et al., 2005, Yoshimura et al., 2005). 
well as in the cranial ganglion IX (glossopharyngeal) and $X$ (vagus ganglion) cells. Consistent with the exclusion of CRMP4 from the proliferating cells of the neural tube, staining in the eye is found in the central and marginal zones of the retina and is absent from the ciliary marginal zone where proliferating retinoblasts are found (Fig. 20 ).

The regulation of CRMP-4 was studied in ectodermal explants (animal caps) from blastula stage embryos; these explants are normally fated to become epidermal tissue, but can be converted to derivatives of all three germ layers. The animal blastomeres of two-cell stage Xenopus embryos were injected bilaterally with mRNA encoding putative regulators and animal caps were dissected at blastula stage. Total RNA was isolated at stage 14 and analyzed by RT-PCR. As shown in Fig. 3A,

A
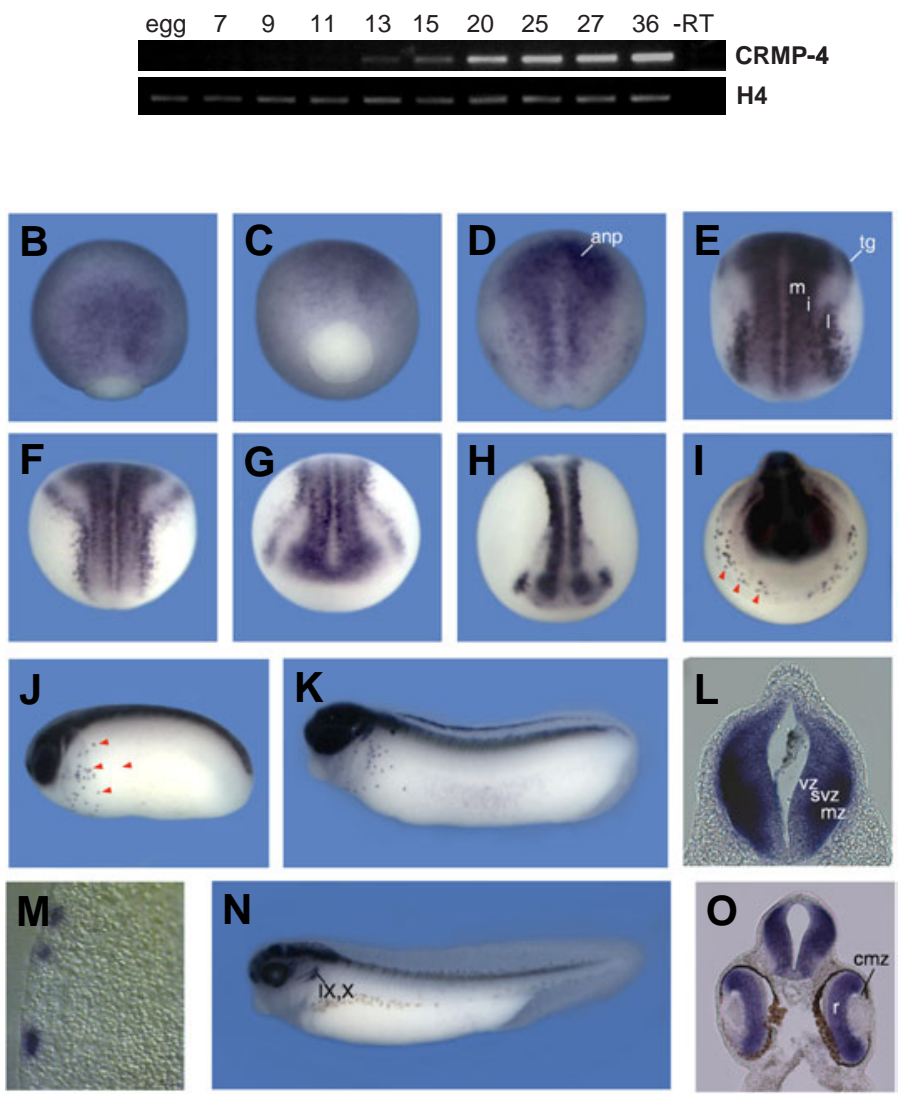

animal caps neuralized with the BMP inhibitor Noggin exhibited strong induction of NCAMas compared with uninjected animal caps, but no influence on CRMP-4 expression was observed. This is in contrast to the regulation of the closely related CRMP2 , which is activated by Noggin (Figure $3 \mathrm{~A}$ and Kamata et al., 1998). The neuronal determination factor X-ngnr-1 robustly induced the activation of both CRMP-4 and CRMP-2. The positive regulation of $C R M P-2$ by $\mathrm{X}$-ngnr-1 is similar to the activation of other panneural genes such as Nrp-1 and NCAM (Klisch et al., 2006).

The regulation of $C R M P-4$ was also investigated in whole embryos. mRNAs encoding putative regulatory factors were injected into one blastomere of two-cell stage embryos together with $L a c Z$ mRNA to localize the distribution of the injected mRNA. Consistent with the results from the animal cap assay, in whole embryos, X-ngnr-1 ectopically activated CRMP-4 within the neural and non-neural ectoderm $(100 \%, n=50$; Fig. 3B). In addition to its proneural activity, X-ngnr-1 activates the Notch pathway in the neighboring cell, thereby restricting the number of cells that undergo neuronal differentiation. Overexpression of the intracellular domain of Notch1 receptor (NotchICD), which functions as a constitutively active form of Notch

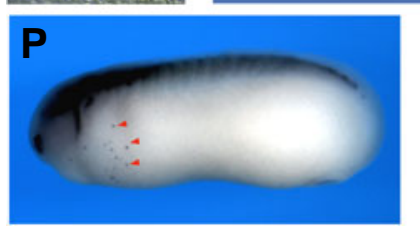

Fig. 2 (Left). Expression of Xenopus CRMP-4. (A) Temporal expression of CRMP-4 determined by RT-PCR at various stages of Xenopus development. The ubiquitous marker Histone H4 served as a loading control. (B-O) Xenopus embryos at the indicated stages were analyzed by whole mount in situ hybridization using a digoxigeninlabelled CRMP-4 antisense probe. (B) Stage 11.5 d., (C) stage 11.5, veg., (D) stage 12.5 ., (E) stage $14 d$., (F) stage 15 d., (G) stage 15 ant., (H) stage 16 d-ant., (I) stage 19 ant., (J) stage 24, (K) stage 28, (L) transversal section of $(K)$ through the spinal chord, $(\mathbf{M})$ transversal section of $(K)$ showing through the punctuate anteriorlateral cells, (N) stage 37, lat., (O) transversal section of (N) through the midbrain region. (P) $N$-tubulin antisense probe, stage 27. anp, anterior neural plate; ant, anterior; cmz, cilliary marginal zone; d, dorsal; i, intermediate; I, lateral; mz, marginal zone; m, medial; r, retina; svz, subventricular zone; tg, trigeminal placode; veg, vegetal; vz, ventricular zone; IX, glossopharngeal ganglion; $X$, vagus ganglion. Red arrowheads indicate scattered cells.

Fig. 3 (Right). Regulation of CRMP-4. (A) Xenopus embryos were injected bilaterally with Noggin (50 pg) or X-ngnr-1 (25 pg) and animal caps excised at the blastula stage. When sibling embryos reached stage 14 , the caps were collected, total RNA isolated and RT-PCR analysis performed. Histone $\mathrm{H} 4$ served as a loading control. (B) Whole mount in situ hybridization of stage 14 embryos injected with sense RNA encoding X-ngnr-1 (25 pg) or Notch-ICD (50 pg) in one blastomere at the two-cell stage. 
(Coffman et al., 1993), inhibits CRMP-4 expression on the injected side ( $97 \%, n=57$; Fig. $3 B$ ).

Taken together, the temporal expression pattern observed in the territories of primary neurogenesis, as well as the regulation of $C R M P-4$ by Notch signaling and $\mathrm{X}$-ngnr-1, support an early role for CRMP-4 in neuronal precursor cells as they initiate differentiation during primary neurogenesis. Both expression and regulation of $C R M P-4$ differ from that of $C R M P-2$, which is induced by the events of neural induction. It will be of interest to elucidate the function of CRMP-4 during the differentiation of primary neurons in Xenopus, as the CRMP family has primarily been characterized during neuronal maturation in mammalian systems.

\section{Experimental Procedures}

\section{Xenopus CRMP-4}

CRMP-4 was identified in a XenopuscDNA library obtained from the German Resource Center for Genome Research (IMAGE ID: 4408246, Accession number BC082618). The Xenopus CRMP-4 cDNA clone contained 1909 bp insert comprising 146 bp of 5'-UTR, 1713 bp of coding sequence and 50 bp of 3'-UTR in pCMVSport6.

Xenopus embryo collection and whole mount in situ hybridization Xenopus laevis embryos were obtained by HCG induced egglaying, dejellied in $2 \%$ cysteine $\mathrm{pH} 8.0$, washed and cultured in $0.1 \mathrm{X}$ MBS. Embryos were fixed in MEMFA at the desired stage according to Nieuwkoop and Faber (1967). The spatial expression patterns were determined by whole mount in situhybridization (Harland, 1991) using a DIG labelled antisense probe. XCRMP-4pCMVSport6 was linearized with EcoRI and transcribed with T7 polymerase. Embryos were embedded in gelatine and $30 \mu \mathrm{m}$ sections were prepared using a vibratome.

\section{Microinjection of embryos}

Capped mRNA for microinjections were prepared by in vitro transcription (mMessage-mMachine ${ }^{\mathrm{TM}}$ Ambion) and purified over an RNeasy column (Qiagen). Embryos were injected in one or both blastomere of the two-cell stage with the indicated amount of RNA: $50 \mathrm{pg}$ Noggin (Smith et al., 1993), 50 pg Notch-/CD (Coffman et al., 1993), 25 pg Xngnr-1 (Ma et al., 1996). As a lineage tracer, $50 \mathrm{pg}$ nuclear lacZmRNA was coinjected (Chitnis et al., 1995).

\section{Animal cap assay and RT-PCR}

Two-cell stage embryos were injected bilaterally, animal caps dissected from stage 8-9 embryos and cultured until sibling controls reached stage 14. Total RNA was extracted from the various embryonic stages or animal caps (Qiagen RNeasy Kit) and cDNA prepared using random hexamer primers and MuLV reverse transcriptase (PerkinElmer). PCR was performed with Taq polymerase using the following gene specific oligonucleotide primer pairs:

Histone H4 (26 cycles)

forward: 5'-CGGGATAACATTCAGGGTATCACT-3'

reverse: 5'-ATCCATGGCGGTAACTGTCTTCCT-3'

NCAM (32 cycles)

forward: 5'-CACAGTTCCACCAAATGC-3'

reverse: 5'-GGAATCAAGCGGT5ACAGA-3' (Hemmati-Brivanlou and Melton, 1994).

$N$-tubulin (28 cycles)

forward: 5'-ACACGGCATTGATCCTACAG-3'

reverse: 5'-AGCTCCTTCGGTGTAATGAC-3' (Good et al., 1989).

CRMP-2 (30 cycles)

forward: 5'-GGAGAACATGGTTCACACTA-3'

reverse: 5'-TGCAGCATTTGTACTGGTGAC-3' (Kamata et al., 1998).
CRMP-4 (28 cycles)

forward: 5'-GGAACATTGGCGAGAGAGAAC-3'

reverse: 5'-GTTGTCTCCAATCTGCTTGAT-3'.

\section{Acknowledgements}

We thank K. Ditter for excellent technical assistance. This work was supported by a grant from the DFG (CMPB) to T.P. and T.K. was supported by a Lichtenberg stipend in the International Ph.D. Molecular Biology Program, International Max Planck Research School University of Goettingen.

\section{References}

ARIMURA, N., INAGAKI, N., CHIHARA, K., MENAGER, C., NAKAMURA, N., AMANO, M., IWAMATSU, A., GOSHIMA, Y. and KAIBUCHI, K. (2000). Phosphorylation of collapsin response mediator protein-2 by Rho-kinase. Evidence for two separate signaling pathways for growth cone collapse. J. Biol. Chem. 275: 23973-80.

ARIMURA, N., MENAGER, C., FUKATA, Y. and KAIBUCHI, K. (2004). Role of CRMP-2 in neuronal polarity. J. Neurobiol. 58: 34-47.

ARIMURA, N., MENAGER, C., KAWANO, Y., YOSHIMURA, T., KAWABATA, S., HATTORI, A., FUKATA, Y., AMANO, M., GOSHIMA, Y., INAGAKI, M., MORONE, N., USUKURA, J. and KAIBUCHI, K. (2005). Phosphorylation by Rho kinase regulates CRMP-2 activity in growth cones. Mol. Cell. Biol. 25: 9973-84.

CHARRIER, E., REIBEL, S., ROGEMOND, V., AGUERA, M., THOMASSET, N. and HONNORAT, J. (2003). Collapsin response mediator proteins (CRMPs): involvement in nervous system development and adult neurodegenerative disorders. Mol. Neurobiol. 28: 51-64.

CHITNIS, A., HENRIQUE, D., LEWIS J., ISH-HOROWICZ, D. and KINTNER, C. (1995). Primary neurogenesis in Xenopus embryos regulated by a homologue of the Drosophila neurogenic gene Delta. Nature 375: 761-6.

COFFMAN, C.R., SKOGLUND, P., HARRIS, W.A. AND KINTNER, C.R. (1993). Expression of an extracellular deletion of Xotch diverts cell fate in Xenopus embryos. Cel/73: 659-71.

COlE, A.R., CAUSERET, F., YADIRGI, G., hASTIE, C.J., MCLAUCHLAN, H., MCMANUS, E.J., HERNANDEZ, F., EICKHOLT, B.J., NIKOLIC, M. and SUTHERLAND, C. (2006). Distinct priming kinases contribute to differential regulation of collapsin response mediator proteins by glycogen synthase kinase-3 in vivo. J. Biol. Chem. 281: 16591-8.

FUKATA, Y., ITOH, T. J., KIMURA, T., MENAGER, C., NISHIMURA, T., SHIROMIZU, T., WATANABE, H., INAGAKI, N., IWAMATSU, A., HOTANI, H. and KAIBUCHI, K. (2002). CRMP-2 binds to tubulin heterodimers to promote microtubule assembly. Nat. Cell Biol. 4: 583-91.

GOOD, P.J., RICHTER, K. and DAWID, I.B. (1989). The sequence of a nervous system-specific, class II beta-tubulin gene from Xenopus laevis. Nucleic Acids Res. 17: 8000.

GOSHIMA, Y., NAKAMURA, F., STRITTMATTER, P. and STRITTMATTER, S.M. (1995). Collapsin-induced growth cone collapse mediated by an intracellular protein related to UNC-33. Nature 376: 509-14.

HARLAND, R.M. (1991). In situ hybridization: an improved whole mount method for" Xenopus embryos. Methods Cell Biol. 36: 685-95.

HEMMATI-BRIVANLOU, A. and MELTON, D.A. (1994). Inhibition of activin receptor signaling promotes neuralization in Xenopus. Cel/77: 273-81.

INAGAKI, N., CHIHARA, K., ARIMURA, N., MENAGER, C., KAWANO, Y., MATSUO, N., NISHIMURA, T., AMANO, M. and KAIBUCHI, K. (2001). CRMP-2 induces axons in cultured hippocampal neurons. Nat. Neurosci. 4: 781-2.

KAMATA, T., DAAR, I.O., SUBLESKI, M., COPELAND, T., KUNG, H.F. and XU, R.H. (1998). Xenopus CRMP-2 is an early response gene to neural induction. Brain Res. Mol. Brain Res. 57: 201-10.

KLISCH, T.J., SOUOPGUI, J., JUERGENS, K., RUST, B., PIELER, T. and HENNINGFELD, K.A. (2006). Dev. Biol. 292: 470-85.

LLANOS, S., EFEYAN, A., MONSECH, J., DOMINGUEZ, O. and SERRANO, M. (2006). A High-Throughput Loss-of-Function Screening Identifies Novel p53 Regulators. Cell Cycle 5: 1880-5.

MA, Q., CHEN, Z., DEL BARCO BARRANTES, I., DE LA POMPA, J.L. and 
ANDERSON, D.J. (1998). Neurogenin1 is essential for the determination of neuronal precursors for proximal cranial sensory ganglia. Neuron 20: 469-82.

NIEUWKOOP, P.D. and FABER, J. (1967). Normal Table of Xenopus laevis (Daudin), $2^{\text {nd }}$ ed. Elsevier/North Holland, Amsterdam.

NISHIMURA, T., FUKATA, Y., KATO, K., YAMAGUCHI, T., MATSUURA, Y., KAMIGUCHI, H. and KAIBUCHI, K. (2003). CRMP-2 regulates polarized Numbmediated endocytosis for axon growth. Nat. Cell Biol. 5: 819-26.

OSCHWALD, R., RICHTER, K. and GRUNZ, H. (1991). Localization of a nervous system-specific class II beta-tubulin gene in Xenopus laevis embryos by whole mount in situ hybridization. Int. J. Dev. Biol. 35: 399-405.

PAPALOPULU, N. and KINTNER, C. (1996). A posteriorising factor, retinoic acid, reveals that anteroposterior patterning controls the timing of neuronal differentiation in Xenopus neuroectoderm. Development 122: 3409-18.

SMITH, W.C., KNECHT, A.K., WU M. and HARLAND, R.M. (1993). Secreted noggin protein mimics the Spemann organizer in dorsalizing Xenopus mesoderm. Nature 361: 547-9.

SMITH, S.J., KOTECHA, S., TOWERS, N. and MOHUN, T. J. (2000). Xenopus Hand2 expression marks anterior vascular progenitors but not the developing heart. Dev. Dyn. 219: 575-81.

TAHIMIC, C.G., TOMIMATSU, N., NISHIGAKI, R., FUKUHARA, A., TODA, T., KAIBUCHI, K., SHIOTA, G., OSHIMURA, M. and KURIMASA, A. (2006). Evidence for a role of Collapsin response mediator protein-2 in signaling pathways that regulate the proliferation of non-neuronal cells. Biochem. Bio- phys. Res. Commun. 340: 1244-50.

TALIKKA, M., STEFANI, G., BRIVANLOU, A.H. and ZIMMERMAN, K. (2004). Characterization of Xenopus Phox2a and Phox $2 \mathrm{~b}$ defines expression domains within the embryonic nervous system and early heart field. Gene Expr. Patterns 4: 601-7.

UCHIDA, Y., OHSHIMA, T., SASAKI, Y., SUZUKI, H., YANAI, S., YAMASHITA, N., NAKAMURA, F., TAKEI, K., IHARA, Y., MIKOSHIBA, K., KOLATTUKUDY, P., HONNORAT, J. and GOSHIMA, Y. (2005). Semaphorin3A signalling is mediated via sequential Cdk5 and GSK3beta phosphorylation of CRMP2: implication of common phosphorylating mechanism underlying axon guidance and Alzheimer's disease. Genes Cells 10: 165-79.

WANG, L.H. and STRITTMATTER, S.M. (1996). A family of rat CRMP genes is differentially expressed in the nervous system. J. Neurosci. 16: 6197-207.

WANG, L.H. and STRITTMATTER, S.M. (1997). Brain CRMP forms heterotetramers similar to liver dihydropyrimidinase. J. Neurochem. 69: 2261-9.

YOSHIMURA. T., KAWANO. Y., ARIMURA. N., KAWABATA. S., KIKUCHI. A. and KAIBUCHI. K. (2005). GSK-3beta regulates phosphorylation of CRMP-2 and neuronal polarity. Cel/120: 137-49.

Received: 30th October 2006 Reviewed by Referees: 27th November 2006 Modified by Authors and Accepted for Publication: 29th November 2006 Published Online: 7th March 2007 


\section{The Spemann-Mangold}

\section{Organizer}

Edited by Eddy M. De Robertis and Juan A réchaga

Preface

by E.M. DeR obertis and J. A réchaga

HERITAGE OF THE 1924 ARTICLE BY HANS SPEMANN AND HILDE MANGOLD

Introducing the Spemann-Mangold organizer: experiments and insights that generated a

key concept in developmental biology

by $K$. Sander and P. Faessler

Induction of embryonic primordia by implantation of organizers from a different species

Reprint of the original 1924 article by $\mathrm{H}$ ans Spemann and $\mathrm{H}$ ilde $\mathrm{M}$ angold, translated into

English by Viktor $\mathrm{H}$ amburger

Developmental biology of amphibians after $\mathrm{H}$ ans Spemann in Germany

by H. Grunz

Spemann's heritage in Finnish developmental biology by L. Saxén

Spemann's influence on Japanese developmental biology

by M. A sashima and T. Okada

Contribution of the Belgian school of embryology to the concept of neural induction by the organizer

by $\mathrm{H}$. Alexandre

Contrasting influences of the organizer and induction concepts on the scientific activity of French embryologists

by J.-C. Beetschen and A.-M. Duprat

Consequences of the Spemann-Mangold organizer concept for embryological research in Russia: personal impressions

by A.T. M ikhailov and N.A. Gorgolyuk

The organizer concept and modern embryology: Anglo-American perspectives by $T$. $H$ order

THE ORGANIZER CONCEPT: OVERVIEWS AND THEORETICAL APPROACHES

Evolution of the organizer and the chordate body plan by J. Gerhart

Continuity and change: paradigm shifts in neural induction by S. Gilbert

Formation and maintenance of the organizer among vertebrates by $K$. Joubin and C.D. Stern

O rganizer and axes formation as a self-organizing process by H. M einhardt

ORGANIZER RESEARCH TODAY

Molecular mechanisms of cell-cell signalling by the Spemann-Mangold organizer by E.M. De Robertis, O. Wessely, M. Oelgeschläger, B. Brizuela, E. Pera, J. Larraín, J. A breu and D. Bachiller

Formation of a functional morphogen gradient by a passive process in tissue from the early Xenopus embryo

by N. M CD owell, J.B. Gurdon and D.J. Grainger

A study of Xlim1 function in the Spemann-Mangold organizer

by L. Kodjabachian, A.A. Karavanov, H. Hikasa, N.A. Hukriede, T. A oki, M. T aira and I.B. Dawid

Making mesoderm - upstream and downstream of Xbra by J. Smith

Regulation of convergent extension in Xenopus by Wnt5a and Frizzled-8 is independent of the canonical Wnt pathway

by J.B. Wallingford, K.M. Vogeli and R.M. H arland

Generation of the germ layers along the animal-vegetal axis in Xenopus laevis by H. Yasuo and P. Lemaire

Dickkopf 1 and the Spemann-Mangold head organizer by C. Niehrs, O. Kazansakaya, W.Wu, and A. Glinka

Siamois cooperates with TGF $\beta$ signals to induce the complete function of the SpemannMangold organizer

by M.J. Engleka and D. S. Kessler

\section{ORDER FORM}

I would like to order cop(y/ies) of the Int. J. Dev. Biol. Special Issue “The Spemann-Mangold Organizer” (Vol. 45, N 1)

at US\$ 70 or Euro $€ \overline{70}$ per copy (including post and packaging). Total to be charged: US\$ / Euro $€$ (please specify currency)

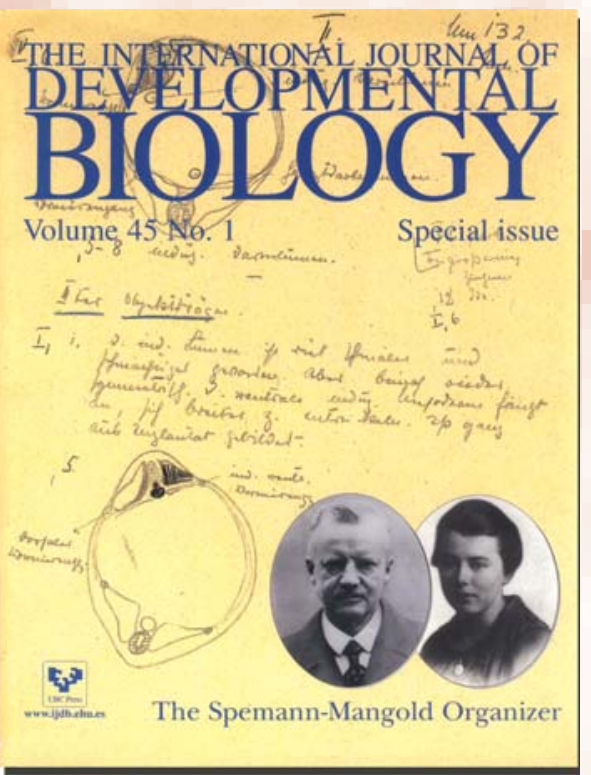

The Spemann-Mangold organizer: the control of fate specification and morphogenetic rearrangements during gastrulation in Xenopus by T. B ouwmeester

Functional analysis of the Xenopus frizzled 7 protein domains using chimeric receptors by R.K. Swain, A. M edina and H. Steinbeisser

Fox (forkhead) genes are involved in the dorso-ventral patterning of the Xenopus mesoderm

by H. El-H odiri, N. Bhatia-Dey, K. Ken yon, K. Ault, M. Dirksen and M. Jamrich

In vitro induction systems for analyses of amphibian organogenesis and body patterning by T. Ariizumi and M. Asashima

The avian organizer

by T. B oettger, H. Knoetgen, L. Wittler and M. Kessel

Nodal signaling and the zebrafish organizer by A.F. Schier and W.S. T albot

The role of the homeodomain protein Bozozok in Zebrafish axis formation by $L$. Solnica-K rezel and W. Driever

Role of the anterior visceral endoderm in restricting posterior signals in the mouse embryo

by A. Perea-Gomez, M. Rhinn and S. -L. Ang

Roles of Sox factors in neural determination: conserved signaling in evolution? by Y. Sasai

G etting your head around $H$ ex and $H$ esxl : forebrain formation in mouse by J.P. M artínez Barbera, R.S.P. Beddington

The role of 0 tx 2 in organizing the anterior patterning in mouse by A. Simeone and D. A campora

Defects of the body plan of mutant embryos lacking Lim1, 0 tx2 or $\mathrm{Hnf3} \beta$ activity by S.J. Kinder, T.E. T sang, S.-L. Ang, R.R. Behringer and P.P.L. T am

0 tx2 and $\mathrm{Hnf} \beta$ genetically interact in anterior patterning by 0 . Jin, K. H arpal, S.L. Ang and J. Rossant

The isthmic organizer and brain regionalization by S. M artínez

Early neurogenesis in amniote vertebrates by N. Le Douarin

\section{ORDER BY}

Web: http://www.intjdevbiol.com

E-mail: ijdb@ehu.es (include the information indicated above)

FAX: $\quad+34-94-601-3266$

FAX: $+34-94-601-3266$

The International Journal of Developmental Biology

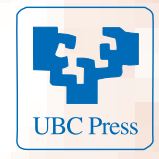

UBC Press - Editorial Service University of the Basque Country E-48940 Leioa, (Vizcaya)

SPAIN 